\title{
Can Peer to Peer Interaction (PPI) be a Global Theme to Promote Engagement in Students of Diverse Characteristics and Country Contexts?
}

\author{
Nazlee Siddiqui* \\ University of Tasmania, Australia \\ https://orcid.org/0000-0002-1841-3095 \\ Khasro Miah \\ North South University, Bangladesh \\ https://orcid.org/0000-0002-6499-3545 \\ Afreen Ahmad Hasnain \\ Southeast University, Bangladesh \\ https://orcid.org/0000-0002-4474-6942 \\ David Greenfield \\ University of Tasmania, Australia \\ https://orcid.org/0000-0002-0927-6025
}

\begin{abstract}
Investigating postgraduate students' experience of peer-topeer interaction (PPI) to promote engagement, across diverse student characteristics and country contexts, is rare, but a task necessary to improve outcomes for increasingly diverse students in higher education. This study implemented a questionnaire survey in an Asian developing (i.e. Bangladesh; $\mathrm{n}=65$ ) and a Western developed country (i.e., Australia; $\mathrm{n}=28$ ) to address two research questions: first, is student experience of PPI to promote engagement consistent across developing and developed country contexts? Second, do characteristics of students influence their experience of PPI? In both contexts, PPI facilitated students' discussion of readings from different viewpoints, cognition to apply classroom learning to work and teamwork and practical problem-solving skills. In the developed country, students' age negatively correlated to engagement with readings $(\mathrm{r}=-.644)$ and cognition of applying classroom learning to work ( $\mathrm{r}=-$-649). In the developing country, age did not impact on the experience of PPI, whereas a lack of adequate technology had a negative impact. Working students in the developed country, unlike that of the developing country, were critical of relying on peers, reflecting the influence of individualism cultural orientation. The study implies PPIs can be a global theme to promote student engagement if developed in alignment with the pedagogy of social constructivism and academic and cognitive student engagement themes.
\end{abstract}


Furthermore, academics should design PPIs in partnership with students, accommodating the PPIs to the characteristics of relevant student cohorts and contexts. Future studies of a greater sample size will facilitate the agenda for effective PPIs for all students.

Keywords: Peer-to-peer interaction; Diversity of students; Pupils engagement; Student engagement; Developed country

\section{Introduction}

Investigation of student engagement is a decades' old journey, but at the same time, it is an ongoing agenda in education systems (Holmes, 2018). Scholars indicate a global trend of increasing student diversity in higher education (Andrew, 2019; Perez, Robbins, Harris, \& Montgomery, 2020; Sanger, 2020; Tanaka, 2019; Universities Australia, 2019). How student diversity shapes the themes of student engagement is an evolving process. Peer to peer interaction (PPI) is recognised as a common theme of student engagement (Kahu \& Nelson, 2018; Zhoc, Webster, Li, \& Chung, 2018). Understanding of the PPI is also evolving, being an important aspect of ongoing investigations of student engagement (Siddiqui, Miah, \& Ahmad, 2019).

PPI is a learning and teaching practice that is frequently used in higher education(Beaumont, Mannion, \& Shen, 2012; Power \& Vaughan, 2010; Stigmar, 2016). It involves students working collaboratively with a common purpose in real-time, in one to one or small teams, either in the face to face or online mode. PPI has to negotiate with diversity factors at a contextual level such as the different technology platforms, teacher's capability, and level of resource availability in the learning environment (Jawhar \& Subahi, 2020; Kahu \& Nelson, 2018). Moreover, PPI practices rely on students' personal capability to socially interact with peers who are likely to be of different profiles, for example, by lifestyle (working versus non-working) or culture (local versus international) or age (matured versus young).

It has become necessary to critically investigate the interrelation between PPI and enhanced student engagement, across students from different countries, to inform the macro contextual factors involved in this interrelationship. Moreover, investigations are required to identify PPI learning and teaching approaches that can be accommodated to benefit all students, at a micro-level, regardless of students' personal capability and characteristics. The premise of the investigations lies in PPI being a learning activity that is influenced by individual students and the surrounding social world (Broer, Bai, \& Fonseca, 2019; Lave \& Wenger, 1991). Academics who are aware of how PPI is experienced by students of divergent backgrounds at the macro, as well as micro levels, will be better equipped to facilitating an inclusive learning environment (Lawrie et al., 2017). Moreover, academics with such awareness can promote a generalised learner-centered approach for collaborative learning (Hoidn, 2016).

Authors find that studies of comparative assessment of PPI between students of different contexts are rare. An exception is a study of Lam et al. (2016) that 
reported an insignificant influence of PPI in school students' engagement across twelve European, the United States of America (USA), and Southeast Asian countries. It is possible that the situation in higher education is different from what is reported at schools. Previous literature evidenced the beneficial influence of PPI in higher education across different countries, but also pointed out that more than $60 \%$ of studies in the review belonged to the western education context (Stigmar, 2016). The study of PPI in Asian developing country contexts is underrepresented (Siddiqui et al., 2019) and a comparative assessment of PPI between contrasting education contexts (for example, developing versus developed country) is exceptional.

\subsection{Research Questions}

This study investigates students' experience of PPI in promoting engagement, with an application of the same PPI assessment across students of two divergent country contexts. The two research questions addressed in this study are:

Question 1: Is student experience of PPI to promote engagement consistent across developing and developed country contexts?

Question 2: Do characteristics of students influence their experience of PPI?

\subsection{PPI and engagement of students of different characteristics and contexts}

In the early literature of student engagement, for example in the work of Astin (1984); the phenomenon was described as students' overall involvement in the learning experience to yield desirable academic achievements. Further research has clarified student engagement as a multi-dimensional phenomenon; consisting of emotional, behavioural, cognitive and sociocultural themes (Bowden, Tickle, \& Naumann, 2019; Zhoc et al., 2018).

According to the contemporary framework of student engagement by Zhoc et al (2018), PPI builds student engagement through social interaction with peers. This theme includes collaborative academic learning, as well as, beyond the classroom interactions between student peers. The theme of PPI functions side by side to the other four themes of student engagement, which are: academic engagement, covering online and offline student behaviours to achieve academic learning; cognitive engagement, consisting of students' psychological investment to master knowledge; social engagement with teachers, encompassing supportive interactions between teacher and student in the academic environment; and affective engagement, encompassing students' emotional bonding with the learning institution (Zhoc et al., 2018).

The literature provides consistent evidence of PPI's role in student engagement in higher education. Globally, in developed countries such as the USA (National Survey of Student Engagement, 2019), United Kingdom (Neves, 2019), Australia (Coates, 2010; Quality indicators for learning and teaching, 2020); learning with peers is a common theme in the national survey of student engagement in higher education. A foundational literature to understand students' experience of PPI is the pedagogy of social constructivism, which proposes students achieve deeper learning with constructive peer interactions (Powell \& Kalina, 2009). Academics need to spend substantial time and 
resources to design PPIs with features of social constructivism such as critical thinking, collaborative tasks and the task being meaningful to students (Powell \& Kalina, 2009; Siddiqui, Miah, \& Ahmad, 2019; Van Bergen \& Parsell, 2019). Students experiencing effective PPIs were reported to have greater success with teamwork and enhancement of skills such as problem-solving, communication, learning autonomy, work related cognition and ethical thinking (Siddiqui et al., 2019; Stigmar, 2016; University of the Free State, 2019).

However, current literature, as summarised above, provides a generalised appreciation of the interrelation between PPI and enhanced student engagement. It does not provide insights into how students' age, gender, race, religion, cultural orientation, sexual orientation, working and non-working and socioeconomic country contexts (developing versus developed) (Andrew, 2019; Sanger, 2020) influence the interrelation between PPI and student engagement. Kahu and Nelson's conceptual framework of student engagement supports the notion that students' experience of PPI is subjective to their cultural background and the learning institute's resources (Kahu \& Nelson, 2018). Previous research also reported students' gender (Lam et al., 2016), working versus non-working status (Creed, French, \& Hood, 2015), cultural dimensions such as individualism versus collectivism (Morera \& Galván , 2019) and developed versus developing country contexts (Ming Ming \& Chow, 2011) are important considerations to understand students' learning process. Furthermore, learning is a product of engagement between the person participating in education and the surrounding social world (Broer, Bai, \& Fonseca, 2019; Lave \& Wenger, 1991). Hence, the experience of an academic assessment of PPI is expected to be influenced by students' various characteristics and country contexts.

\section{Method}

\subsection{Research context and Participants}

The sample students for this study were selected from two different postgraduate management units located in an Asian developing and Western developed country (United Nations, 2014) respectively, Bangladesh and Australia.

The developing country education setting is a private university, with subject ranking for management, in the range of 401-450 by Quacquarelli Symonds(QS) World university ranking (QS World University Rankings, 2020). The developed country educational setting is a public university, with an overall QS ranking of 291(QS World University Rankings, 2020). Two of the authors are academics in the chosen universities in the two countries. Hence the universities and classes were chosen purposively, following the criteria of knowledge of the class's course curriculum, and access to designing of the PPI assessment. Fulfillment of the selection criteria was essential to effectively develop the PPI assessment and investigate the research phenomenon.

Sample students from the university in developing and developed countries were studying in face to face and blended learning mode, respectively. In terms of cultural orientation, the developing country is of the collectivism dimension, with a score of 20 (Hofstede Insights, 2020). This score reflects students in this 
country belonged to a society that upholds strong relationships and commitment among group members. On the other hand, the developed country is high on the individualism dimension, with a score of 90 (Hofstede Insights, 2020). So, students in this country belonged to a self-reliant society where a reward is based on individual merit. Upon comparing two cases in contrasting contexts, the study applied the extreme-comparative method (Shelly, Ooi, \& Brown, 2019) to draw learning on PPI's functioning with student engagement.

The sample cohort in the developing country comprised of sixty-five students, representing $80 \%$ of the class. This cohort largely represented students aged below 30 at $60 \%$ and females at $58 \%$. The developed country sample consisted of twenty-eight students, representing $38 \%$ of the class. Out of this cohort, aged 30 years and older and females were $61 \%$ and $75 \%$ respectively. Around $35 \%$ and $96 \%$ of students were working and studying simultaneously, in the developing and developed countries, respectively. There were no international students in any of the sample cohorts. Students from the developing country represented the Indian ethnicity at $100 \%$ and the religion of Islam at $97 \%$. Students from the developed country largely represented the British ethnicity at $75 \%$ and the religion of Christianity at $89 \%$. The extracted sample from each class provided sufficient information to answer the research questions regarding a student's experience of PPI. Hence the sample size was justified by informationorientation, being adequate to investigate the targeted phenomenon in this mixed methods education research (Ahrens \& Zascerinska, 2014; Onwuegbuzie, \& Collins, 2007).

\subsection{Research design and procedure}

This research collected quantitative and qualitative perspective of students' experience of a PPI assessment, applying a cross-sectional survey, within the convergent parallel mixed methods research design (Creswell, 2014). In both the study contexts, the survey took place after students experienced the PPI assessment. The assessment was part of the study in the semester. The study was first conducted at the university in the developed country, in 2017, and later in 2018, in the university in the developing country.

The PPI assessment was designed with the concept of social constructivism (Powell \& Kalina, 2009; Vygotsky, 1962). Accordingly, the assessment incorporated collaborative tasks, critical thinking, and content that was relevant to students' topics of learning. The PPI was a real-time learning activity (online/audio discussion in real-time), where 3-5 students collaborated as a team and made two submissions. One, a submission of 350-400 words answer to a question that students wrote as a team. As explained in an earlier publication of the researchers (reference is withheld to facilitate blind peer review), to answer the question, the team members needed to be oriented with the unit readings. In this submission, each team explained how specific learning from the readings could be applied to manage real-life workplace scenarios. The PPI assessment covered $5 \%$ of the total mark of the unit, with the same mark being applied to the whole team. The lecturers/unit coordinators arranged the class into teams of all working students or a combination of working and nonworking students. This arrangement was considered beneficial for students' cognitive engagement towards the application of classroom learning. 
The ethics protocol of the study in the developed country was approved by the human research ethics committee at the Australian University (reference number H0015793). In the absence of a human research ethics committee in the university in Bangladesh, the study followed the guideline of the approved protocol from the Australian University. The survey was voluntary and confidential for all participants, which was important, as researchers were also unit coordinator/lecturer in the investigated units. All enrolled students were invited for the survey, through an announcement in the online learning platform of the unit, for the university in Australia, and the university website, for the university in Bangladesh. In these announcements, a link was provided for students to participate in the survey via survey monkey. Further information on the survey procedure in the developing country, is available in an earlier publication (Siddiqui et al., 2019).

\subsection{Survey Instrument}

The survey instrument was purposely built for this study. A sample of the survey questions is attached in Appendix 1. The survey included a section of nominal scales to capture a student's age, gender, religion, ethnicity, and status of simultaneous work and study. Another section of Likert scales of 1 (Strongly Disagree) to 5 (Strongly Agree) to collect a students' experience of an association between their experience of PPI and student engagement. Two single-item variables in this section were: one, PPI enhances student engagement with reading materials. Two, PPI enhances engagement with thinking of applying classroom learning to work. There was also a section that collected students' opinions in free-text comments (qualitative), regarding their answer on the Likert questions and suggestions to improve the PPI assessment.

\subsection{Data Analysis}

The quantitative and qualitative data analyses were done simultaneously by two separate researchers in this study. As shown in the result section, the research questions were answered, placing the quantitative and qualitative results side by side, with equal importance to each.

Quantitative data were analysed in three main ways. In all analyses, a respondent was excluded if any answer was missing in any question. First, a profile analysis was conducted, using percentage break-down, on the factors of age, gender, religion, ethnicity, and the status of simultaneous work and study. Second, analysis of variance (ANOVA) was completed, at a 95\% confidence level, to compare students' experience of PPI in promoting student engagement between the developing and developed countries. Variables subjected to ANOVA were PPI enhances engagement with reading materials and PPI enhances engagement with thinking of applying classroom learning to work (Table 3). The homogeneity assumption was adhered to as the Levens test reported statistically insignificant variance by median on both the variables. Moreover, the data distribution was not of extreme nature as the absolute value of the kurtosis index for both the variables were below 7 (Byrne, 2016). Lastly, Pearson's correlation, at 99\% confidence level, was conducted within developing and developing country, between the variables of age, gender, ethnicity, religion and PPI enhances engagement with reading materials and PPI enhances engagement with thinking of applying classroom learning to work. The 
correlation analysis assessed the association between students' characteristics and their experience of PPI. The association between the variables was assessed as low, moderate, and high if the value of coefficient correlation (r) were below 0.3 , between 0.3 to below 0.5 and above 0.5 respectively (Cohen, 1988).

The qualitative data (free-text comments) in the survey were analysed, taking guidance from the steps of thematic analysis, coined by Braun and Clarke(2006). The first step was to become familiar with the data, through a reading of each respondent's comments and making notes of initial thoughts. In the second step, all comments were collated in an excel file, in two worksheets, one for the developing country and the other for the developed country data set. These datasets were then reorganised into a set of interesting statements or quotations, according to the research questions. This step ended with labelling a set of quotations into codes such as "different viewpoints of readings" and "readings made interesting". A sample of the coding process is provided in Table 1.

Table 1: Coding process

\begin{tabular}{|l|l|}
\hline Code & Sample quotations from respondents \\
\hline $\begin{array}{l}\text { Readings } \\
\text { interesting }\end{array}$ & $\begin{array}{l}\text { "When we discuss with each other, it is interesting as lots of things are } \\
\text { there which we can connect with the reading materials (Respondent \#3 } \\
\text { from developing country)." } \\
\text { "Peers different point of views made the readings interesting (Respondent } \\
\text { \#30 from developing country)." } \\
\text { "Through online collaboration we discussed so many issues related to our } \\
\text { reading materials. I never found the reading materials so interesting before } \\
\text { (Respondent \#45 from developing country)". }\end{array}$ \\
$\begin{array}{l}\text { "Although I was only assigned a small component to report on, I read up } \\
\text { on my other team members topics so I could fully engage with them } \\
\text { during the discussion. I liked the readings too (Respondent \#27 from } \\
\text { developed country)". }\end{array}$ \\
$\begin{array}{l}\text { "It was great working with other classmates. Not only does it draw } \\
\text { attention more closely to the reading materials, but it also was great to } \\
\text { draw on the readings to provide support and be supported by others in the } \\
\text { class. (Respondent \#28 from developed country)". }\end{array}$ \\
\hline
\end{tabular}

The third step involved identifying initial themes by merging different codes that reflected similar notions. For example, the codes of "different viewpoint of readings" and "readings made interesting" generated the theme of "Discussion of readings from different viewpoints" (Table 2). In the fourth step, the initial themes were reviewed further against all comments to decide the frequency of each theme in the individual data set of the developing and developed countries. In the last two steps, the themes were finalised and named, upon reviewing these for commonalities and divergence between the developing and developed country data sets. If the review detected themes that were different between the two countries, then those themes were reported as "distinct themes". The theme of "challenge with peers in the developed country" (Table 4) is an example of a distinct theme. 


\section{Results}

In this section, the quantitative and qualitative results are presented according to the research questions. The first two sections (3.1 and 3.2) have answered the first research question, "is student experience of PPI to promote engagement consistent across developing and developed country contexts?". The third section (3.3) has answered the second research question, "do characteristics of students influence their experience of PPI?".

\subsection{Similarities in the experience of PPI}

There were similarities in students' experience of PPI in the two divergent contexts, as reported in the quantitative part of the survey. A substantial share of students, that is, $97 \%$ and $50 \%$ from developing and developed countries, respectively, found PPI promotes student engagement.

Students' opinions, provided in the qualitative section of the survey, generated six common themes as presented in Table 2. In this table, the readers will also find the frequency of the themes and sample quotations.

Table 2: Common themes in students' experience of PPI in the divergent countries

\begin{tabular}{|c|c|}
\hline $\begin{array}{l}\text { Common themes } \\
\text { (Frequency) }\end{array}$ & Sample Quotations \\
\hline $\begin{array}{l}\text { Theme 1: Discuss readings } \\
\text { from different viewpoints } \\
\text { (89\% in the developing and } \\
98 \% \text { in developed country) }\end{array}$ & $\begin{array}{l}\text { "Peers different point of views made the readings interesting } \\
\text { (Respondent \#30 from developing country)." } \\
\text { "I'm a clinician, so my level of experience in management is } \\
\text { limited. I was lucky enough that the other members of our } \\
\text { team had experience in this field and could discuss the } \\
\text { readings from their views. I felt really supported in this } \\
\text { format (Respondent \#14 from developed country)." }\end{array}$ \\
\hline $\begin{array}{l}\text { Theme } 2 \text { : Sharing reading } \\
\text { work with peers } \\
\text { (90\% in the developing and } \\
89 \% \text { in developed country) }\end{array}$ & $\begin{array}{l}\text { "I believe group study or peer interaction helps us to quickly } \\
\text { grasp the readings, as we could share the readings and teach } \\
\text { each other what we read online (Respondent \#40 from } \\
\text { developing country)." } \\
\text { "I find this subject incredibly difficult, so sharing the load } \\
\text { with team members and being able to split the content...and } \\
\text { teach each other what we have read about was great } \\
\text { (Respondent \#6 from developed country) }\end{array}$ \\
\hline $\begin{array}{l}\text { Theme 3: Workplace } \\
\text { relevant skill of Shared } \\
\text { learning/teamwork } \\
\text { (82\% in the developing and } \\
73 \% \text { in the developed } \\
\text { country) }\end{array}$ & $\begin{array}{l}\text { "It helped me to increase skills for my work by learning how } \\
\text { to manage a group to be efficient and complete the work } \\
\text { timely. I can apply the same approach with which I } \\
\text { maintained coordination in this peer interaction } \\
\text { (Respondent \#22 from developing country)" } \\
\text { "My other team member has a very different background to } \\
\text { myself and works in a lesser clinical area, so it was good to } \\
\text { hear examples form their workplace also. (Respondent \#3 } \\
\text { from developed country." }\end{array}$ \\
\hline $\begin{array}{l}\text { Theme 4: Workplace } \\
\text { relevant skill of practical } \\
\text { problem- solving }(88 \% \text { in the } \\
\text { developing and } 62 \% \text { in }\end{array}$ & $\begin{array}{l}\text { "There are many issues for which there are no solutions in } \\
\text { the book. Peer interaction helped to talk about these issues } \\
\text { and find practical solutions just like what I do at work. } \\
\text { (Respondent \# } 65 \text { from developing country)". }\end{array}$ \\
\hline
\end{tabular}




\begin{tabular}{|c|l|}
\hline developed country) & $\begin{array}{l}\text { "At work, I always needed to but was afraid of looking into } \\
\text { financial statements. But I found the concept of } \\
\text { 'productivity' and 'efficiency' in the financial statements } \\
\text { interesting, as explained by the team, though a shared } \\
\text { learning process. I plan to explore them for work issues in } \\
\text { the future (Respondent \#8 from developed country). }\end{array}$ \\
\hline $\begin{array}{c}\text { Theme 5: Ease of online } \\
\text { communication with peers } \\
\text { (10\% in the developing and } \\
28 \% \text { in the developed } \\
\text { country) }\end{array}$ & $\begin{array}{l}\text { beat the advantages of online collaboration (Respondent \#40 } \\
\text { from developing country)." }\end{array}$ \\
"The online collaboration gave me the confidence to speak up \\
as I am always nervous to do that (Respondent \#9 from \\
developed country)."
\end{tabular}

The two most frequent themes were the same across the students in developing and developed countries. Which were: theme 1, PPI helped to discuss readings from different viewpoints and theme 2, PPI facilitated sharing of reading work with team members. Students shared their experience of how the PPI was a supportive mechanism to understand the readings from different viewpoints of team members and making the readings interesting (comments from respondent \#30 and \#14 in Table 2). Moreover, across the two contexts, most students agreed that PPI helped to share the load of readings with team members (comments from respondent \#40 and \#6 in Table 2).

In both countries, as shown in themes 3 and 4 in Table 2, PPI came across as a platform to attain workplace relevant skills of shared learning, teamwork, and practical problem-solving. This happened, as during the PPI, students enjoyed learning about the diverse work environment of peers and engaged in joint coordination of the PPI assessment (comments from respondent \# 22 and \# 3 in Table 2). Students also felt an association between PPI and practical problemsolving, since the team discussion allowed unpacking of complex problems in a language that they are familiar with (comments from respondent \# 65 and \#8 in Table 2).

Additionally, as per the theme 5, few students, in both the contexts, resonated with the notion that PPI can make it easy to communicate with peers through online medium. These students found online interaction to be speedy (real-time) and lesser intimidating (comments from respondent \# 40 and \# 9 in Table 2). Lastly, as per the theme 6, few students commented that PPI was not a significant influencer in their learning. This was the least frequent theme in both the contexts and were experienced by students who felt a common hurdle with the PPI assessment was the inadequacy of time (comments from respondents \# 50 and \#2 in Table 2). 


\subsection{Differences in the experience of PPI}

There was a disparity in the level of endorsement for PPI between students in developing and developed countries, as reported in the quantitative part of the survey. As shown in Table 3, comparatively, developing country students provided significantly stronger endorsement on the two variables of PPI enhances engagement with reading materials $\left(\mathrm{F}-\mathrm{value}=12.99^{*}\right)$ and thinking of application of classroom learning to work $\left(\mathrm{F}\right.$-value $\left.=15.83^{*}\right)$.

Table 3: Students' experience of PPI between developing and developed country

\begin{tabular}{|c|c|c|c|c|}
\hline & $\begin{array}{c}\text { Students in } \\
\text { Developing } \\
\text { Country }\end{array}$ & $\begin{array}{c}\text { Students in } \\
\text { Developed } \\
\text { Country }\end{array}$ & $\begin{array}{c}\text { Mean square } \\
\text { between } \\
\text { groups }\end{array}$ & F-value \\
\hline $\mathrm{n}(\%)$ & $62(75)$ & $21(25)$ & & \\
\hline Missing value & 3 & 7 & & \\
\hline \multicolumn{5}{|c|}{ Variable: PPI enhances engagement with reading materials } \\
\hline Mean (SD) & $4.4(.68)$ & $3.6(1.2)$ & 9.25 & $12.99^{*}$ \\
\hline \multicolumn{5}{|c|}{$\begin{array}{l}\text { Variable: PPI enhances engagement with thinking of applying classroom learning to } \\
\text { work }\end{array}$} \\
\hline Mean (SD) & $4.5(.69)$ & $3.7(.85)$ & 8.53 & $15.83^{*}$ \\
\hline
\end{tabular}

* The mean square difference is significant at $\mathrm{P}<.05$ level $(2$ tailed $)$

Table 4 presents themes that pointed to differences in the experience of PPI in the two countries.

Table 4: Distinct themes in the experience of PPI in the divergent countries

\begin{tabular}{|c|l|}
\hline $\begin{array}{c}\text { Distinct Themes } \\
\text { (Frequency) }\end{array}$ & \multicolumn{1}{|c|}{ Sample Quotations } \\
\hline $\begin{array}{c}\text { Theme 1: Improving } \\
\text { PPI with better } \\
\text { technology in the } \\
\text { developing country } \\
\text { (8\%) }\end{array}$ & $\begin{array}{l}\text { "Skype, Facebook services are often not working here. We faced this } \\
\text { problem and completed the task with group messaging and audio } \\
\text { recording on phone (Respondent \#46 from developing country)." } \\
\text { "We talked over WhatsApp/Viber. It was audio conversation, as the } \\
\text { internet could not support video conversation. I wanted the PPI to be } \\
\text { a video conversation, to make it more interesting with capturing of } \\
\text { the facial expressions (Respondent \#52 from developing country). " }\end{array}$ \\
$\begin{array}{c}\text { Theme 2: Challenge } \\
\text { devith peers in the } \\
\text { (18\%) }\end{array}$ & $\begin{array}{l}\text { "My reading of the provided materials was not instigated by the team } \\
\text { project provided a platform to discuss certain readings, though I } \\
\text { found discussion on reading materials to be more engaging with } \\
\text { workplace managers than with fellow students. (Respondent \#4 from } \\
\text { developed country)." }\end{array}$ \\
& $\begin{array}{l}\text { Members were difficult to engage early on. While I am very quick to } \\
\text { reply to emails and correspondence back and forth, it was more } \\
\text { difficult with other members who were not so engaged. (Respondent } \\
\text { \#8 from developed country). }\end{array}$ \\
\hline
\end{tabular}


In the developing country, few students commented on PPI experience being compromised due to technology issues. This notion generated Theme 1 , which is, improving PPI with better technology. This theme, as reported in Table 4, indicated students had difficulty in accessing Facebook/Skype and resorted to phone recording for the PPI (comment from respondent \#46). A student also felt the need for video technology to make the PPI experience more interesting (comment from respondent \#52).

In the analysis of qualitative comments, few students in the developed country were found to be more critical of the benefits of PPI. Theme 2, challenges with peers, which is reported in Table 4, was drawn from this notion. According to this theme, students felt that discussion of readings with work colleagues was more engaging than the same with peers (comment from respondent \#4). Some students also indicated that PPI can be ineffective if all team members do not equally engage with PPI (comment from respondent \#8).

\subsection{Influence of student characteristics on students' experience of PPI}

Table 5 presents the quantitative survey results regarding the influence of student characteristics in the experience of PPI.

Table 5: Influence of student characteristics in the experience of PPI

\begin{tabular}{|c|c|c|c|c|c|c|}
\hline \multirow[t]{2}{*}{ Variables } & \multicolumn{3}{|c|}{$\begin{array}{c}\text { Students in } \\
\text { Developing Country } \\
(\mathrm{n}=62 ; \text { missing value }=3)\end{array}$} & \multicolumn{3}{|c|}{$\begin{array}{c}\text { Students in } \\
\text { Developed Country }(n=21 ; \\
\text { missing value }=7)\end{array}$} \\
\hline & 1 & 2 & 3 & 1 & 2 & 3 \\
\hline 1. Age & 1 & .093 & .07 & 1 & $-.644^{* *}$ & $-.649^{* *}$ \\
\hline $\begin{array}{l}\text { 2. PPI enhances } \\
\text { engagement } \\
\text { with reading } \\
\text { materials }\end{array}$ & .093 & 1 & $.522^{* *}$ & $-.644^{* *}$ & 1 & $.920 * *$ \\
\hline $\begin{array}{l}\text { 3. PPI enhances } \\
\text { engagement } \\
\text { with thinking } \\
\text { of applying } \\
\text { classroom } \\
\text { learning to } \\
\text { work }\end{array}$ & .07 & $.522^{* *}$ & 1 & $-.649 * *$ & $.920 * *$ & 1 \\
\hline
\end{tabular}

** Correlation is significant at $\mathrm{P}<.01$ level ( 2 tailed)

The data revealed no influence of gender, ethnicity, and religion on students' experience of PPI across the developing and developed countries. However, as shown in Table 5, in the developed country, age had a significant and high negative influence on students' experience of PPI. As per which, more aged students felt PPI reduces engagement with readings $(r=-.644)$ and thinking of applying classroom learning to work $(\mathrm{r}=-.649)$. Furthermore, a strong positive correlation was noted between PPI induced engagement with readings and thinking of applying classroom learning to work. This relationship between the two variables applied to students in developing $(\mathrm{r}=.522)$, as well as, developed 
$(\mathrm{r}=.920)$ country. This point is noteworthy, as a cumulative influence of the negative experience of PPI is expected for the aged students in the developed country.

Analysis of qualitative comments in the survey generated two themes regarding how student characteristics influenced the experience of PPI in both countries. Table 6 presents these themes for students of each country, along with the frequency and sample quotations.

Table 6: Themes for the influence of student characteristics on the experience of PPI

\begin{tabular}{|c|c|}
\hline Themes & Sample Quotations \\
\hline $\begin{array}{c}\text { Theme 1: } \\
\text { Characteristic of } \\
\text { working versus Non- } \\
\text { working influenced } \\
\text { students' experience } \\
\text { of PPI ( } 26 \% \text { in } \\
\text { developing and } 18 \% \\
\text { in developed } \\
\text { country) }\end{array}$ & $\begin{array}{l}\text { "Since I am working in corporate environment, it definitely helped me } \\
\text { to think how I should implement these theories in my workplace } \\
\text { (Respondent \#33 from developing country)". } \\
\text { "I was hesitant with group discussions, as I am not working and can't } \\
\text { provide practical examples. (Respondent \#53 from developing } \\
\text { context)." } \\
\text { "Difficult to engage team members due to ranging work } \\
\text { patterns. Would find it easier to review material on my own and } \\
\text { submit a discussion post (Respondent \#19 from developed } \\
\text { country)." } \\
\text { "It is difficult to process discussion with peers with openness. It could } \\
\text { be good but that is not how we have worked all these years. At an } \\
\text { organisational level, there is not much of taking on different views of } \\
\text { how things could be done (Respondent \#24 from developed } \\
\text { country)." }\end{array}$ \\
\hline $\begin{array}{c}\text { Theme 2: } \\
\text { Characteristic of } \\
\text { Individualism versus } \\
\text { collectivism } \\
\text { influenced students' } \\
\text { experience of PPI } \\
\text { (40\% in developing } \\
\text { and } 57 \% \text { in develop } \\
\text { country) }\end{array}$ & $\begin{array}{l}\text { "My team members despite working full time and also doing masters } \\
\text { full time, managed to match time with others and collaboratively } \\
\text { completed the work. It was not an easy task, but we did it because we } \\
\text { were committed to team's success in this assessment (Respondent \#63 } \\
\text { from developing country)." } \\
\text { "I liked the PPI because it gave a better chance to know strengths and } \\
\text { weaknesses of team members. This kind of online collaboration will } \\
\text { help to networking and allow different walks of people to work as a } \\
\text { team (Respondent \#44 from developing country). } \\
\text { "Everyone comes to the Masters with their own reason and goals. You } \\
\text { are not necessarily working with people that are like minded and this is } \\
\text { always challenging when you are being assessed on group work } \\
\text { (Respondent \# 20 from developed country)." } \\
\text { "Same grade for all when the contribution was not equal by all } \\
\text { members... My suggestion: submission of document with detailed } \\
\text { outline of individual group members work; which would include a sign } \\
\text { off from all group members. This would be helpful for markers to mark } \\
\text { the assignment fairly and equally (Respondent \#13 from developed } \\
\text { country)." }\end{array}$ \\
\hline
\end{tabular}


According to theme 1 in Table 6, the characteristic of working versus nonworking had varied influences on the experience of PPI in the two countries. In the developing country, working students had a positive experience with PPI. This happened, as familiarity with the work environment helped them to imagine how to apply the learning from PPI to work (comment from respondent \#33). Some non-working students were also hesitant with PPIs, for not being able to contribute to the discussion due to lack of work experience (comment from respondent \#53).

In contrast, in the developed country, few working students struggled to synchronise meeting time with other working peers (comment from respondent \#19). Moreover, they were hesitant to receive peer's opinion with openness, claiming that such openness is at odds with their work practices (comment from respondent \#24).

Theme 2 in Table 6, notes the cultural characteristic of Individualism versus collectivism influenced students' experience of PPI. Students in the developing context exhibited a collectivism cultural dimension that positively influenced their experience of PPI. They commented on successful experience with PPI, due to all members' commitment to the success of the team (comment from respondent \#63). Few other students perceived PPI to be a good mechanism to know the capability of team members (comment from respondent \#44). Moreover, they imagined PPI to facilitate networking and teamwork with people of different professions and contexts.

On the other hand, individualism characteristic was evidenced in students in the developed country. In line with the individualism characteristic, they were uncomfortable to rely on team members and the PPI assessment being assessed on the basis of group work (comment from respondent \#20). Moreover, some students wanted to document all team member's contribution, to enhance fairness in marking of the PPI (comment from respondent \# 13)

\section{Discussions}

This study investigated the experience of PPI between students in an Asian developing country versus a Western developed country. Current literature on PPI and student engagement are skewed towards the western setting (Stigmar, 2016) and equally lacking of a comparative view of contrasting contexts. This is a study that compared students' experience of PPI in promoting student engagement, between developing versus developed country contexts, as well as, student's age, gender, ethnicity, religion, cultural orientation, and working versus non-working status.

The first core finding in this study is a substantial portion of students, across the developing and developed country, had a positive experience of PPI in promoting student engagement. Common mechanisms behind the positive experience of PPI were the sharing of tasks and open discussion with peers. It was important that peers had the capability to offer different viewpoints or come from a variety of study or work backgrounds such as clinical versus management (Swain, 2013). This insight is aligned with the previous literature that reported how students benefit from active and collaborative tasks, 
pedagogy of social constructivism and social engagement with peers (Powell \& Kalina, 2009; Van Bergen \& Parsell, 2019; Zhoc et al., 2018). Across the countries, PPI facilitated greater involvement with and understanding of academic readings. This is evidence of PPI's linkage to the theme of students' academic engagement (Zhoc et al., 2018). Furthermore, the study evidenced PPI to help students in attaining workplace relevant skills (for example, teamwork and practical problem-solving) and enhancing cognition to apply classroom learning to work scenarios. This insight is in line with earlier reported benefits of PPI (Stigmar, 2016) and endorses PPI's interaction with the theme of students' cognitive engagement (Zhoc et al., 2018).

The above finding implies PPI can be used as a global theme to promote student engagement across developing and developed countries. It is seen that PPI has the universal capability to enhance engagement, regardless of students' context or individual characteristics. However, a required precondition is that academics will need to design the PPIs within the pedagogy of social constructivism. Moreover, PPIs will need to be designed in alignment with the other themes in the student engagement framework, for example, academic and cognitive engagement, to ensure greater benefit for students (Zhoc et al., 2018). The above finding also contrasted the reporting of insignificant influence of PPI on school students' affective, behavioural and cognitive engagement (Lam et al., 2016). The contrasting evidence supports PPI can differently function between the school and higher education contexts. Future study of how the role of PPI in student engagement is distinguished in higher education, against the school studies, can assist in developing more context suitable PPI practices.

The second core finding in this study is student's experience of PPI to promote engagement is influenced by the technology in the context. It was seen that lack of adequate technology in the developing country, negatively impacted students' experience of PPI. Unlike the previous literature (Holzweiss, Joyner, Fuller, Henderson, \& Young, 2014; MacNeill, Telner, Sparaggis-Agaliotis, \& Hanna, 2014), this study did not find technical difficulties compromised students' experience of PPI in the developed country. This could reflect advancement in technology-enhanced education in the developed country i.e. Australia (Horvath et al., 2019). In comparison, the technology condition (for example, availability of a university's own online learning platform or access to social media such as Facebook) is much inferior in higher education in the developing country (Siddiqui et al., 2019). However, most students in the developing country benefited from the tested PPI assessment despite the technical difficulties. This infers academics in the developing country should not refrain from PPI assessments on account of inferior technology. They should design PPI practices carefully, either face to face or online, mitigating possible influence of inferior technology to students' cognitive, behavioural, and affective engagement (Bodily, Leary, \& West, 2019).

The other core finding is that the interrelation between students' experience of PPI and enhanced engagement is influenced by students' cultural orientation, working versus non-working status, and age. This finding is similar to certain previous literature (Creed et al., 2015; Morera \& Galván, 2019) that reported these specific student characteristics to be important considerations in students' 
learning. The study further clarified that the nature of the influence of a specific student characteristic, varied between developing versus developed countries. For instance, in the developing country, students' age did not influence the experience of PPI in promoting engagement. Whereas, for more aged students in the developed country, PPI reduced their academic as well as cognitive engagement. Hence, academics need to recognise students' age as an important characteristic of influence when designing PPI. Academics in the developed country may need to give greater guidance throughout the PPI experience if the aged students are involved.

Working students behaved differently in the two countries. This cohort of students in the developing country showed collectivism, in line with the country's cultural dimension (Hofstede Insights, 2020), and reflected a stronger commitment for the success of the PPI assessment. In contrast, working students in the developed country portrayed individualistic cultural orientation and were doubtful of the team's commitment to the PPI assessment. Therefore, PPI's role to promote student engagement is shaped by the combined functioning of various characteristics, for instance, work status and cultural orientation of students. An overall implication of the study findings is academics should design PPIs in partnership with students to ensure enhanced student engagement.

The proposed partnership will help to accommodate PPI learning and teaching approaches to diverse characteristics of the relevant student cohort and context. For example, a partnership between academics and students can explore ways to empower mature students in a developed country or international students from Asian backgrounds towards inclusive and more effective PPI experience. PPIs could be designed with a combination of face to face and online interactions; if these students are finding it harder to open up to peers in an online environment. Academics in the developed country may provide more consultation hours to teams with working students, exchanging opinions on PPI design and associated benefits with greater clarity. The rationale of partnership, as authors have proposed here, resonates with recognising students as partners in learning and teaching (Higgins, Dennis, Stoddard, Maier, \& Howitt, 2019) and will facilitate accommodating PPI exercises to the need of diverse student cohorts.

\section{Conclusion}

This study evidenced similarities and differences in students' experience of PPI in promoting engagement in an Asian developing and a Western developed country. Notwithstanding, PPI was endorsed as a global theme that can promote student engagement across the divergent contexts. It was noted that PPIs will have the universal capacity to enhance student engagement if designed with alignment to academic and cognitive engagement themes. Moreover, the pedagogy of social constructivism should guide the development and practice of PPI. Factors such as available technology in the country context and students' age, cultural orientation and working status influenced the role of PPI in enhancing student engagement. It was also seen that student characteristics of age and cultural orientation (i.e., individualism versus collectivism) had influenced the PPI experience differently between students in developing and 
developed countries. Hence, the study confirms the characteristics of students influence their experience of PPI. The implication is academics and students should partner in PPI teaching and learning practices, facilitating the accommodation of the PPIs to the various need of diverse student cohorts. Amidst the growing diversity of students in higher education, such partnerships will promote PPIs that are inclusive and effective for all students.

\section{Limitations}

There were a few limitations in this study. The sample profile of students in both the developed and developing country was female dominant. While the female dominance is reflective of the student population in higher education in the developed country(Universities Australia, 2019), that is not the case for the developing country(World Bank, 2019). Furthermore, the study has drawn sample from only one university and discipline from each country and did not mirror the respective population by characteristics such as age, work status, ethnicity, and religion. Hence, the findings of the study are not generalisable to the respective higher education population. The sample size of the study was also small for a quantitative check of the causal relationship between diversity factors and students' experience of PPI. The study did not follow an experimental design, which raised restriction to apply in-depth statistical comparisons of the experience of PPI between the different cohorts of students. Nevertheless, the study captured students' empirical experience of PPI with mixed methods research design, highlighting critical considerations for the effectiveness of PPI with a diverse cohort of students. Future studies with a greater number of participants are needed to pursue the agenda for effective PPIs for all students.

\section{References}

Ahrens, A., \& Zascerinska, J. (2014). A framework for selecting sample size in educational research on E-Business application. 2014 11th International Conference on e-Business (ICE-B), 39-46.

Andrew, P. (2019). The Quest for Diversity in Higher Education. Pepperdine Policy Review, 11(4). Retrieved from https://digitalcommons.pepperdine.edu/ppr/vol11/iss1/4

Astin, A. (1984). Student Involvement: A Development Theory for Higher Education. Journal of College Student Development, 40, 518-529.

Beaumont, T., Mannion, A., \& Shen, B. (2012). From the Campus to the Cloud: The Online Peer Assisted Learning Scheme. Journal of Peer Learning, 5(6), 20-31.

Bodily, R., Leary, H., \& West, R. E. (2019). Research trends in instructional design and technology journals. British Journal of Educational Technology, 50(1), 64-79. doi:10.1111/bjet.12712

Bowden, J. L.-H., Tickle, L., \& Naumann, K. (2019). The four pillars of tertiary student engagement and success: a holistic measurement approach. Studies in Higher Education, 1-18. doi:10.1080/03075079.2019.1672647

Braun, V., \& Clarke, V. (2006). Using thematic analysis in psychology. Qualitative Research in Psychology, 3, 77-101. doi:10.1191/1478088706qp063oa

Broer, M., Bai, Y., \& Fonseca, F. (2019). A Review of the Literature on Socioeconomic Status and Educational Achievement. In M. Broer, Y. Bai, \& F. Fonseca (Eds.), 
Socioeconomic Inequality and Educational Outcomes: Evidence from Twenty Years of TIMSS (pp. 7-17). Cham: Springer International Publishing.

Byrne, B. M. (2016). Structural Equation Modeling with AMOS: Basic Concepts, Applications, and Programming (3rd ed.). New York: Routledge.

Coates, H. (2010). Development of the Australasian survey of student engagement (AUSSE). Higher Education, 60(1), 1-17. doi:10.1007/s10734-009-9281-2

Cohen, J. (1988). Statistical Power Analysis for the Behavioral Sciences. New York, NY: Routledge Academic

Creed, P. A., French, J., \& Hood, M. (2015). Working while studying at university: The relationship between work benefits and demands and engagement and wellbeing. Journal of Vocational Behavior, 86(Supplement C), 48-57. doi:https://doi.org/10.1016/j.jvb.2014.11.002

Creswell, J. W. (2014). Research design: Qualitative, quantitative, and mixed methods approaches (4th ed. ed.). Thousand Oaks, CA: Sage.

Higgins, D., Dennis, A., Stoddard, A., Maier, A. G., \& Howitt, S. (2019). 'Power to empower': conceptions of teaching and learning in a pedagogical co-design partnership. Higher Education Research and Development, 38(6).

Hofstede Insights. (2020). Country Comparison. Retrieved from https://www.hofstedeinsights.com / country-comparison/

Hoidn, S. (2016). Student-Centered Learning Environments in Higher Education Classrooms. New York, United States: Palgrave Macmillan.

Holmes, N. (2018). Engaging with assessment: Increasing student engagement through continuous assessment. Active Learning in Higher Education, 19(1), 23-34. doi:10.1177/1469787417723230

Holzweiss, P. C., Joyner, S. A., Fuller, M. B., Henderson, S., \& Young, R. (2014). Online graduate students' perceptions of best learning experiences. Distance Education, 35(3), 311-323. doi:10.1080/01587919.2015.955262

Horvath, D., Stirling, E., Bevacqua, J., Coldrey, M., Buultjens, P., Buultjens, M., \& Larsen, A. (2019). Plan, prepare and connect: How investing in understanding and tracking the evolving needs of online students informs the development of targeted programs for transition and success. Journal of University Teaching and Learning Practice, 16(1).

Jawhar, S., \& Subahi, A. (2020). The Impact of Specialty, Sex, Qualification, and Experience on Teachers' Assessment Literacy at Saudi Higher Education. International Journal of Learning, Teaching and Educational Research, 19, 200-216. doi:10.26803/ijlter.19.5.12

Kahu, E. R., \& Nelson, K. (2018). Student engagement in the educational interface: understanding the mechanisms of student success. Higher Education Research $\mathcal{E}$ Development, 37(1), 58-71. doi:10.1080/07294360.2017.1344197

Lam, S.-f., Jimerson, S., Shin, H., Cefai, C., Veiga, F. H., Hatzichristou, C., . . Zollneritsch, J. (2016). Cultural universality and specificity of student engagement in school: The results of an international study from 12 countries. British Journal of Educational Psychology, 86(1), 137-153. doi:10.1111/bjep.12079

Lave, J., \& Wenger, E. (1991). Situated learning: Legitimate peripheral participation . Cambridge:Cambridge University Press. doi:10.1017/CBO9780511815355

Lawrie, G., Marquis, E., Fuller, E., Newman, T., Qiu, M., Nomikoudis, M., . . van Dam, L. (2017). Moving Towards Inclusive Learning and Teaching: A Synthesis of Recent Literature. Teaching Eamp; Learning Inquiry, 5(1), 1-13. doi:10.20343/teachlearninqu.5.1.3

MacNeill, H., Telner, D., Sparaggis-Agaliotis, A., \& Hanna, E. (2014). All for One and One for All: Understanding Health Professionals' Experience in Individual 
Versus Collaborative Online Learning. Journal of Continuing Education in the Health Professions, 34(2), 102-111. doi:10.1002/chp.21226

Ming Ming, C., \& Chow, B. W. Y. (2011). Classroom Discipline Across Forty-One Countries: School, Economic, and Cultural Differences. Journal of Cross-Cultural Psychology, 42(3), 516-533. doi:10.1177/0022022110381115

Morera, I. \& Galván, C. (2019). Hofstede's Cultural Dimensions In The Educational Context. VIII International conference on intercultural education and International conference on transcultural health: The value of education and health for a global,transcultural world. The European Proceedings of Social \& Behavioural Sciences Retrived from https://www.europeanproceedings.com/files/data/article/85/5276/article_85 _5276_pdf_100.pdf

National Survey of Student Engagement. (2019). NSSE 2019 overview. Retrieved from https:// safesupportivelearning.ed.gov/resources/national-survey-studentengagement-2019-overview

Neves, J. (2019). UK Engagement Survey 2019. Retrieved from https://www.advancehe.ac.uk / knowledge-hub / uk-engagement-survey-2019

Onwuegbuzie, A. J., \& Collins, K. M. T. (2007). A typology of mixed methods sampling designs in social science research. The Qualitative Report, 12(2), 281.

Perez, R. J., Robbins, C., Harris, L., \& Montgomery, C. (2020). Exploring Graduate Students' Socialization to Equity, Diversity, and Inclusion. Journal of Diversity in Higher Education, 13, 133-145. Retrieved from https://doi.org/10.1037/dhe0000115

Powell, K. C., \& Kalina, C. J. (2009). Cognitive and Social Constructivism: Developing Tools for an Effective Classroom. Education, 130(2), 241-250. Retrieved from /login?url=http://search.ebscohost.com/login.aspx?direct=true\&db=eric\&AN= EJ871658\&site=eds-livehttp://www.projectinnovation.biz/education_2006.html

Power, M., \& Vaughan, N. (2010). Redesigning Online Learning for International Graduate Seminar Delivery. The Journal of Distance Education / Revue de l'ducation Distance, 24(2), 19-38.

QS World University Rankings. (2020). QS Top Universities. Retrieved from https:// www.topuniversities.com/universities/north-south-university\#923555

Quality indicators for learning and teaching. (2020). 2019 Student Experience Survey. Retrieved from https://www.qilt.edu.au/docs/default-source/ses/ses2019/2019-ses-national-report.pdf?sfvrsn=6486ec3c_10

Sanger, C. S. (2020). Diversity, Inclusion, and Context in Asian Higher Education. In C. S. Sanger \& N. W. Gleason (Eds.), Diversity and Inclusion in Global Higher Education: Lessons from Across Asia (pp. 1-28). Singapore: Springer Singapore.

Shelly, B., Ooi, C.-S., \& Brown, N. (2019). Playful learning? An extreme comparison of the Children's University in Malaysia and in Australia. Journal of Apllied Learning and Teaching, 2(1), 16-23. Retrieved from https://www.semanticscholar.org/paper/ Playful-learning-An-extremecomparison-of-the-in-in-Shelley Ooi/ec66ffefbe4779f504a749f84b210e430f4b0d4f

Siddiqui, N., Miah, K., \& Ahmad, A. (2019). Peer to Peer Synchronous Interaction and Student Engagement: A Perspective of Postgraduate Management Students in a Developing Country. American Journal of Educational Research, 7(7), 491-498. Retrieved from http://pubs.sciepub.com/

Stigmar, M. (2016). Peer-to-peer Teaching in Higher Education: A Critical Literature Review. Mentoring $\mathcal{E}$ Tutoring: Partnership in Learning, 24, 1-13. doi:10.1080/13611267.2016.1178963 
Swain, G. (2013). Diversity Education Goals in Higher Education: A Policy Discourse Analysis. (Doctor of Philosophy (PhD)). University of Maine, Electronic Theses and Dissertations. Retrieved from https://digitalcommons.library.umaine.edu/etd/1957

Tanaka, M. (2019). The international diversity of student engagement. In M. Tanaka (Ed.), Student Engagement and Quality Assurance in Higher Education,1, (. London: Rutledge.

United Nations. (2014). World economic situation prospects. Retrieved from https://www.un.org

/en/development/desa/policy/wesp/wesp_current/2014wesp_country_classi fication.pdf

Universities Australia. (2019). Higher education: facts and figures. Retrieved from https://www.universitiesaustralia.edu.au /wpcontent/uploads/2019/08/190716-Facts-and-Figures-2019-Final-v2.pdf

University of the Free State. (2019). Creating pathwy for student success. Retrieved from https://www.ufs.ac.za/sasse/sasse-home

Van Bergen, P., \& Parsell, M. (2019). Comparing radical, social and psychological constructivism in Australian higher education: a psycho-philosophical perspective. The Australian Educational Researcher, 46(1), 41-58. doi:10.1007/s13384-018-0285-8

Vygotsky, L. S. (1962). Thought and language. Cambridge: M.I.T. Press, Massachusetts Institute of Technology.

World Bank. (2019). Bangladesh Tertiary Education Sector Review: Skills and Innovation for Growth. Retrieved from Washington DC 20433 http://documents.worldbank.org/curated/en/303961553747212653/pdf/Bangl adesh-Tertiary-Education-Sector-Review-Skills-and-Innovation-for-Growth.pdf

Zhoc, K., Webster, B., Li, J., \& Chung, T. (2018). Higher Education Student Engagement Scale (HESES): Development and Psychometric Evidence. Research in Higher Education. doi:10.1007/s11162-018-9510-6 


\section{Appendix I. Survey Instrument (sample questions)}

i) The assessment that I experienced with my peers (other students in the course), as part of the study in this postgraduate course, enhanced my engagement with the reading materials?

Please choose any ONE of the options below and clarify the chosen option

1. Strongly Disagree 2. Disagree 3. Neutral 4. Agree 5. Strongly Agree

Why:

ii) The assessment that I experienced with my peers (other students in the course), as part of the study in this postgraduate course, made me think of ways to apply learning from this course to workplace scenarios?

Please choose any ONE of the options below and clarify the chosen option

1. Strongly Disagree 2. Disagree 3. Neutral 4. Agree 5. Strongly Agree

Why:

iii) I would like to recommend the following changes so that the assessment I experienced with my peers could be more useful to enhance my overall learning experience in this course:

iv) Please answer the following questions

- What is your gender:

- What is your age

- What is your religion:

- What is your ethnicity:

- Education completed (Please choose only one option): a) Bachelor from Private University in Bangladesh b) Bachelor from a public university in Bangladesh c) Others

- Are you studying (Please choose only one option): a) Part-time b) Fulltime c) Studying and working simultaneously d) Others 